\title{
Support For Nurses Directly \\ Involved with Women who Chose To Terminate A Pregnancy
}

AC GMEINER

Ph.D.

Senior lecturer: Nursing Science RAU

$\&$

$S$ VAN WYK

Ph.D.

Lecturer: Nursing Science

RAU

\&

\section{POGGENPOEL}

Ph.D.

Professor: Nursing Science

RAU

\&

\section{CPH MYBURGH}

D. Ed.

Professor: Education Sciences RAU

\begin{abstract}
Research conducted by Poggenpoel, Myburgh and Gmeiner (1998:2-8) on "One voice regarding the legalization of abortion: Nurses who experience discomfort" indicated that the nurses were in favour of the fact that nurses should volunteer to participate in terminating a pregnancy of a woman. From our observations in clinics where nurses voluntarily participate in providing reproductive health services, including termination of pregnancy, it became clear that supporting these nurses may be essential. To be able to provide support, it is necessary to identify, explore and describe nurses' experience of being directly involved with women who terminate their pregnancy.

To enable us to address the identified problems, a qualitative research strategy was implemented in which respondents were included in the sample through purposive sampling. Phenomenological interviews were conducted individually. Data was analysed by means of Tesch's descriptive approach. Thereafter, guidelines for operationalisation were inferred from the results and a literature control completed to verify and enrich guidelines. Measures to ensure trustworthiness have been applied in the research and ethical measures have been strictly adhered to regarding this sensitive issue.
\end{abstract}

\section{Opsomming}

Navorsing gedoen deur Poggenpoel, Myburgh en Gmeiner (1998:2-8) getiteld: "One voice regarding the legalization of abortion: Nurses who experience discomfort" het aangedui dat verpleegkundiges ten gunste van die vrywillige deelname aan die beëindiging van ' $n$ vrou se swangerskap is. Ons waarnemings in klinieke waar verpleegkundiges vrywillig betrokke is by die verskaffing van reproduktiewe gesondheidsdienste, insluitend die beëindiging van swangerskap, het duidelik getoon dat dit noodsaaklik mag wees om hierdie verpleegkundiges te ondersteun. Dit is nodig om verpleegkundiges se belewing van direkte betrokkenheid by vrouens wat hulle swangerskappe beëindig, te identifiseer, te ondersoek en te beskryf om sodoende die nodige ondersteuning te kan bied.

' $n$ Kwalitatiewe navorsingstrategie is geïmplementeer om die geïdentifiseerde probleme aan te spreek en deelnemers is deur middel van doelgerigte keuring ingesluit in die steekproef. Individuele fenomenologiese onderhoude is gevoer. Data is geanaliseer volgens Tesch se beskrywende benadering. Daarna is riglyne vir operasionalisering saamgestel vanuit die resultate bekom en ' $n$ literatuurkontrole is uitgevoer om die riglyne te valideer en te verryk. Maatreëls om vertrouenswaardigheid te verseker is toegepas in die navorsing en etiese maatreëls is streng toegepas as gevolg van die sensitiwiteit van die onderwerp.

\section{Rationale and Problem statement}

Since 1994, with the election of the Government of National Unity and the democratization of the South African society, many changes have taken place that also directly influence the health care delivery system in South Africa.

In the health care service delivery system particularly, women's health became a priority to be attended to - specifically their reproductive choices and their own health. This entail that they may also choose to terminate a pregnancy as stated in the Freedom of Choice of Terminating Pregnancy (Act no. 92 of 1996). Since February 1997, more than 160000 terminations of pregnancy have been carried out (Badenhorst, 1999:13). The impact of this large number of terminations on 
the health delivery system is enormous. Little provision has been made in the infrastructure to absorb this reality (Beeld, 1997:5; Poggenpoel, Myburgh \& Gmeiner, 1998:3). Not enough well prepared professionals, clinics and finances are available.

The nursing profession in particular, has been directly influenced by the impact of the legalization of women's freedom of choice to terminate their pregnancy. Large numbers of nurses refuse to be involved in the nursing of women who chose to terminate their pregnancy (Barometer, 1997:8). In research conducted by Poggenpoel, Myburgh and Gmeiner (1998:2-8) on "One voice regarding the legalization of abortion: Nurses who experience discomfort", they identified five major themes regarding the termination of pregnancy. These five themes are: the freedom of choice of nurses to provide support before, during and after the termination of pregnancy; negative perceptions regarding the woman who requested a termination of pregnancy and staff providing a termination; the need for information to women, the community and nurses; turmoil regarding life versus death, and recommendations from nurses regarding the management of termination of pregnancy.

From these results it became clear that the nurses were in favour of the fact that nurses may freely choose to be directly involved with the execution of the procedure.

From our observations in clinics where nurses voluntarily participate in providing reproductive health services including termination of pregnancy, it has become clear that supporting these nurses may be essential. To be able to provide support, it is necessary to identify, explore and describe the nurses' experience of being directly involved with women who terminate their pregnancy.

Little or no research has been conducted to explore and describe the experience of nurses directly involved in the termination of a pregnancy by a woman, or the support they need or receive.

\section{Research Aims}

Two aims were formulated for the research project described in this paper:

- The exploration and description of nurses' experiences of being directly involved with women's termination of their pregnancy; and

- The description of support needed to assist nurses who provide this service.

- The focus in this article is on describing guidelines for support of nurses directly involved with women's termination of their pregnancy.

\section{Research Design}

A qualitative, explorative, descriptive and contextual research design was utilized to conduct this research (Mouton \& Marais, 1992:45,175; Mouton, 1996:103-169).

The focus was to obtain data that would facilitate understanding of nurses' experiences of being directly involved with women who terminate their pregnancy. This understanding forms the basis for describing support guidelines to assist these nurses.

\section{Research Method}

The research was conducted in two phases.

Phase 1: The exploration and description of nurses' experi- ence of being directly involved with women's termination of their pregnancy

In phase 1 attention will be given to sampling, data gathering, data analysis and literature control. The issues regarding trustworthiness and ethics will further be addressed.

Sampling: Respondents were included by way of purposive sampling (Creswell, 1994:15). The criteria for inclusion were: nurses who are voluntary directly involved with women who choose to terminate their pregnancy and who consent to participate in the research.

Data collection: Data was gathered by means of phenomenological interviews and field notes.

Phenomenological interviews (Kvale, 1996:81-107; Marshall \& Rossman, 1995:80-83; Omery, 1983:61) were conducted with respondents. These interviews focused on the lived experience of each specific respondent (Poggenpoel \& Myburgh, 1999:2). One central question was posed, namely:

"How did you experience being directly involved with a woman's termination of her pregnancy?"

The interviewer created a context where the respondents could speak freely and openly by utilizing communication techniques such as clarification, paraphrasing, summarizing, probing and minimal verbal as well as non-verbal response (Wilson \& Kneisl, 1996:110-131).

During the interviews the interviewer used bracketing (placing preconceived ideas aside) and intuiting (focusing on the lived experiences of the respondents regarding the termination of a pregnancy). The interviews were conducted until the data was saturated as demonstrated by repeated themes.

The interviewer wrote field notes based on observations made during interviews. These field notes addressed the interviewer's observations, personal experience, methodological issues and theoretical notes (Wilson, 1989:436-438).

Data analysis: Data was descriptively analysed using Tesch's (in Creswell, 1994:154-156) method of descriptive analysis. An independent coder analysed data independently from the various researchers (Creswell, 1994:158; Krefting, 1990:216). Consensus discussions were held between the independent coder and researchers and identified themes were refined. A literature control was done to verify the results (Poggenpoel, 1993:3).

Measures to ensure trustworthiness were applied. Guba's (Lincoln \& Guba, 1985:290-327) strategies of credibility, transferability, dependability and confirmability were applied. Activities in achieving credibility were prolonged engagement in the field, keeping reflexive journals, the researcher's authority, triangulation, peer review and structural coherence. Transferability was achieved through a dense description of the data and purposive sampling. Dependability was achieved by a description of the method of data gathering, data analysis and interpretation. Finally, confirmability was achieved by ensuring an audit of the entire research process, reflexive analysis and triangulation.

Ethical measures (Democratic Nurses Association of South Africa, 1998:7) were adhered to during the research regarding this sensitive issue. These included ensuring quality of the research, informed consent of respondents, ensuring confidentiality and anonymity, protection from harm and providing feedback on the project to the respondents. 
Phase 2: The description of support guidelines to assist nurses directly involved with a woman's termination of her pregnancy

Data gathering: Inference (Copi, 1986:57) was used to identify support guidelines from the results obtained in phase 1.

Data analysis: These were discussed with caring professionals to ensure trustworthiness. Thereafter a literature control was done.

\section{Results And Discussion}

Five major categories were identified from the experiences of nurses directly involved with women's termination of their pregnancy. Refer to Table 1 for an overview of major categories, subcategories and direct quotes from nurses directly involved with termination of pregnancy. These categories and subcategories will only be referred to briefly, as the focus of this article is on guidelines for support of nurses directly involved with termination of pregnancy.

Description of guidelines for support of nurses directly involved with women who chose to terminate a pregnancy

From the results of interviews on nurses' experience of being directly involved with termination of pregnancy as depicted in table 1, it can be inferred that they need support.

Support for these nurses will be provided by means of a continuos support group based on Yalom's $(1985 ; 1-500)$ approach of group therapy. The time frame for these groups can be many weeks or months. The goal for the advanced psychiatric nurse practitioner will be to build cohesiveness over many sessions, and allow the nurses involved with termination of

\section{Table 1: An overview of major categories and subcategories of the results of nurses' experience of being directly involved with termination of pregnancy}

\begin{tabular}{|c|c|c|}
\hline Main category & Subcategory & Direct quotes \\
\hline $\begin{array}{l}\text { 1.Legalization perceived } \\
\text { as a positive step }\end{array}$ & & $\begin{array}{l}\text { "I think it is good to be done by professional doctors, } \\
\text { unlike it is done illegally where they can get killed in a } \\
\text { backyard." }\end{array}$ \\
\hline $\begin{array}{l}\text { 2.Direct involvement results } \\
\text { in the reliving of personal } \\
\text { trauma. }\end{array}$ & $\begin{array}{l}\text { Positively: } \\
\text { Develop therapeutic abili- } \\
\text { ties (empathy, uncondi- } \\
\text { tional accep-tance and } \\
\text { respect). } \\
\text { Less positive: } \\
\text { value conflict } \\
\text { emotional fatigue/ de- } \\
\text { pression } \\
\text { becoming moralistic and } \\
\text { judgmental }\end{array}$ & $\begin{array}{l}\text { "I see what they go through and I relive it every day and } \\
\text { I don't want them to go through it like I did." } \\
\text { "I'm sure I would have felt different if it wasn't that I went } \\
\text { through this myself, I think this is my greatest motivation } \\
\text { for helping them." } \\
\text { "It is not nice to be there with the patient, you know, you } \\
\text { just feel you can walk out" } \\
\text { and } \\
\text { "...hearing all of this makes me feel helpless, frightened } \\
\text { and tired and you don't know... you are still confused." }\end{array}$ \\
\hline $\begin{array}{l}\text { 3.Psychological defense } \\
\text { mechanisms as shield of } \\
\text { protection against own emo- } \\
\text { tional pain. }\end{array}$ & $\begin{array}{l}\text { Rationalization } \\
\text { Intellectualization } \\
\text { Externalization } \\
\text { Denial }\end{array}$ & $\begin{array}{l}\text { "Look, I find that I justify why I do what I do, when you } \\
\text { see so much neglect, so much harm coming to kids, that } \\
\text { you think to yourself. This is rather better." } \\
\text { "... from my point of view and from the woman's right } \\
\text { point of view, I am a person that is very gender sensitive } \\
\text { and I did gender as a study..." } \\
\text { "They experience it as very traumatic, they didn't know it } \\
\text { was going to be so bad... it is difficult to define the inten- } \\
\text { sity of the pain and you can never prepare them psycho- } \\
\text { logically." } \\
\text { "It is better that way, to look at it as a job... it is better and } \\
\text { then at the same time you give them advice." }\end{array}$ \\
\hline $\begin{array}{l}\text { 4. Hosting secretiveness as a } \\
\text { way of protection against } \\
\text { victimi-zation and stigmati- } \\
\text { zation }\end{array}$ & & $\begin{array}{l}\text { "It affected my child's life months after.. I can stand up } \\
\text { on my own, but she cannot... I tell them that I work in a } \\
\text { family planning clinic and I never explain further." }\end{array}$ \\
\hline $\begin{array}{l}\text { 5. Need for support voiced } \\
\text { by nurses }\end{array}$ & $\begin{array}{l}\text { Cognitive } \\
\text { - } \quad \text { Emotional } \\
\text { - Spiritual }\end{array}$ & $\begin{array}{l}\text { "We can go on a lecture for a week or two and this can } \\
\text { also help me a lot to become more skillful." } \\
\text { "We need a kind of meeting where we can talk about our } \\
\text { experiences... where we can go to and off-load." } \\
\text { "I encourage myself by praying and relieve myself from } \\
\text { this pain... I don't know what else to do about the pain." }\end{array}$ \\
\hline
\end{tabular}

The above results are discussed in more depth in Gmeiner, Van Wyk, Poggenpoel \& Myburgh, 1999 - Unpublished article). 
pregnancy to describe their experiences, share their feelings, and assess their strengths. The main goal will be to support nurses involved with termination of pregnancy to express and find new meaning in their every day experiences, through discussing and entering their experiences in their reflective diaries. Short-term goals might focus on involving the nurses involved with termination of pregnancy in a support debriefing process, verbalisation of experiences and listening to other experiences, decreasing isolation and providing support for others. The story needs to be told from group meeting to next group meeting. As Yalom (1985: 467) states:" group therapy is often cyclotherapy, because they must return again and again to the same issues in the therapeutic work".

Support group interventions in this context will provide a unique opportunity for nurses involved with women who chose to terminate a pregnancy to feel accepted, trusted, cared for and supported by others. Yalom (1985:3-18) describes these factors of feeling accepted, cared for, trusted and supported, as therapeutic factors. He suggests that therapeutic change is an enormously complex process and occurs through an intricate interplay of various guided human experiences. These factors are: catharsis (ability to ventilate feelings/experiences), group as a second family; awareness (thoughts, feelings and/ or bodily responses); group cohesiveness (involvement); receiving information; imitative behaviour (modeling); faith and giving and receiving help. The nurses involved with termination of pregnancy will also have the opportunity to get insight into the universal commonness of their feelings, ideas and behaviours and will appear to feel a sense of caring or love for one another.

In providing support, members receive through giving - not only as part of the reciprocal giving-receiving sequence, but also from the intrinsic act of giving. The experience of finding that you can be important to others is refreshing and boosts self-esteem (Yalom, 1985:14). The value of this support group then lies in the following story:

"There is an old hasidic story of a Rabbi who had a conversation with the Lord about Heaven and Hell. "I will show you Hell," said the Lord and led the Rabbi into a room in the middle of which was a very big round table. The people sitting at it were famished and desperate. In the middle of the table there was an enormous pot of stew, more than enough for everyone. The smell of the stew was delicious and made the Rabbi's mouth water. The people around the table were holding spoons with very long handles. Each person found that it was just possible to reach the pot to take a spoonful of the stew, but because the handle of the spoon was longer than anyone's arm, no one could get the food into his mouth. The Rabbi saw that their suffering was indeed terrible! "Now I will show you heaven," said the Lord, and they went into another room, exactly the same as the first. There was the same big round table and the same enormous pot of stew. The people, as before, were equipped with the same long-handled spoons, but here they were well nourished and plump, laughing and talking. At first the Rabbi could not understand. "It is simple, but it requires a certain skill," said the Lord. "You see, they have learned to feed each other!"

Yalom's approach to support in a group, within the context of narrative therapy will be utilized in providing guidelines to assist nurses directly involved with women choosing to terminate a pregnancy. Figure 1 depicts a conceptual framework for the support group. The figure will now be discussed.

The goal of this support group as we conceptualized it will be to support the nurses to work through their own personal trauma, psychological defense mechanisms, hosting secre- tiveness and their need for support

The group's task might be to help members overcome feelings of self-contempt, loneliness, alienation and disengagement and to help them attach new and different meanings to their experiences through reflection. The hope is to trigger a small change in the picture or in the nurses' understanding of the picture (Andersen, 1987:427).

\section{Suggested structure of the support group}

\section{Relationship phase (creating a context)}

A context needs to be created where the nurse involved with women who chose to terminate a pregnancy, can develop as a reflective practitioner. The nurse needs to develop the ability and skills to reflect on the influence of the process of abortion on her internal world, and to voice these experiences through utilizing reflective diaries and meanings. Reflective diaries will provide the nurse with the opportunity to enter her interactions into the diary, focusing on the situation, her thoughts, feelings and actions. She will bring this diary to the support group and will be able to discuss issues concerning him/her (Weiner, Caldwell \& Tyson, 1983:179-183). In this way new ideas can be generated for the nurse involved with women who chose to terminate a pregnancy. In the social sciences, at least, it is now generally recognised that it is not possible for people to have a direct knowledge of the world, that an objective description of the world is not available to us and that no-one has privileged access to the naming of reality, whatever reality is. What the nurse involved with the termination of pregnancy know of the world, she/he only knows through experiencing it. The best that can then be done in this support group is to interpret the experiences, that is the expression of experiences as they go about the business of interpreting it for themselves.

To interpret (the interpretation of others) the advanced psychiatric nurse practitioner has to rely on her own lived experience and imagination. The most she can do is to identify her own experience of the experience, as expressed by the group members. Thus "empathy" is a critical factor in the interpretation or understanding of the experiences of these nurses (Epston \& White, 1989-1991)

Certain questions are raised to investigate the ways these nurses make sense of their lives to themselves and others, and focus attention of the processes through which meaning is attributed to experiences. By asking these questions, the meaning these nurses ascribe to their experience, can be deconstructed:

- What process is used by these nurses to develop an understanding of their experience and give meaning to?

- How do they make sense of their experience to themselves, and how do they make sense of their experience to others?

- What processes are involved in their interpretation to articulate their lived experience to themselves and others?

- What facilitates the expression of their experience?

- How does the expression of their lived experience affect their lives and relationships?

In order to give meaning to experience it must be organised, framed and given a pattern (Epston \& White, 1989-1991:79). 
A conceptual framework for the proposed support group

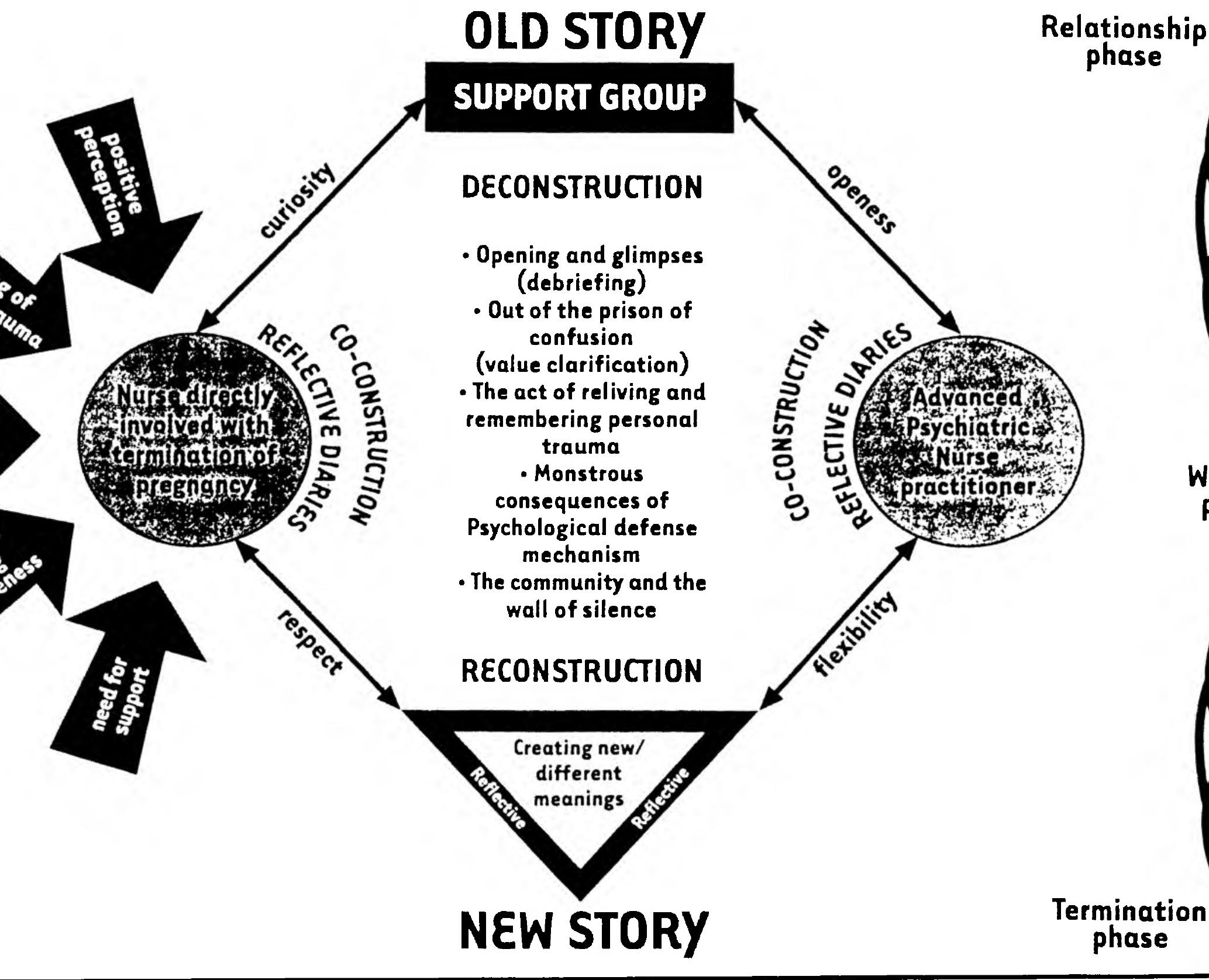


The nature of the frames that facilitate the interpretation of experience needs to be deconstructed. The narrative/story provides the primary frame for this interpretation for the activity of meaning-making; it is through the narratives or stories people have about their own lives and the lives of others, that they make sense of their experience.

For deconstruction to take place the context created by the advanced psychiatric nurse practitioner must be open, flexible, filled with respect and curiosity to facilitate conversation, utilising different facilitative techniques. Circular questioning to map interaction, focusing on behaviour, perceptions, feelings, beliefs and ideas, e.g. "the more you say this the quieter the group becomes". Reflective questioning to facilitate reflection - "what do you think happens to the rest of the group when you do this? " Letter writing as a way of reflection from the therapist. The therapist can write a letter to the group commenting on the process of externalizing problems (Epston, 1994:32). The letter can also act as a mechanism for continuous interaction.

Following is a discussion of a suggested process for the implementation of a support group.

\section{Opening and glimpses}

A decision should be made about who should attend the group (criteria for inclusion) and how many members. Proper pregroup orientation leads to greater member satisfaction, increased group cohesiveness and an increased level of interpersonal exploration (Yalom, 1988:118). The initial interview could be the beginning of support and the nurse involved with termination of pregnancy needs to take the responsibility to decide what she would like to address/share in this process. The success of support groups also depends on the commonalties that members share and should be considered in the initial phase (Weiner, Caldwell \& Tyson, 1983:179-183). It might be suggested that the initial meetings are approached by providing structure, realizing that defense mechanisms play a significant role in providing equilibrium to the nurse involved with the termination of pregnancy and that removing or addressing these too soon, might lead to some of the nurses experiencing a deep sense of sadness and depression too suddenly. Initially, the success of groups is also determined by providing structure (Weiner, Caldwell \& Tyson, 1983:179183).

According to Yalom (1998:121) structure should be provided in the first meeting (opening) commencing by going around the room, giving each nurse involved with the termination of pregnancy, the opportunity to discuss the goals they have, aloud.

It is also imperative that the advanced psychiatric nurse practitioner guides the members in the group right from the beginning to interact directly with other members of the group and explore interactions (activating the here-and-now). Questions should be worded in a non-threatening way for the support group to be beneficial.

In creating the support group McDonald (1994:40) also states that the program should have the full support of all levels of management. Everyone must understand the value of the support group, as one nurse stated: "Even if it's a bad day, you cannot cancel the support group" (McDonald, 1994:40).

Norms need to be set in the opening meeting that include a consistently available meeting room, refreshments and specific times. Perceived safety and privacy of the group is a keystone to its growth (McDonald, 1994:40).

McDonald (1994:40) also suggests that consistent advertis- ing; exploration and recruitment will be needed to attract regular group members. A meeting for six to nine months of the year is a good strategy, taking a break before reconvening.

In this initial opening the nurses should be allowed to share the experiences of their involvement with women who chose to terminate a pregnancy and be allowed to experience a sense of reliving and meaning generation (Barker, 1987:121).

The first two to three meetings could be utilized as debriefing sessions, and a way for the nurse involved with termination of pregnancy, to share his/her feelings and experiences. Debriefing especially focuses on facts, thoughts, reactions and symptoms regarding termination of pregnancy.

The nurse involved with the termination of pregnancy could be encouraged to talk about those aspects with which she/he feels most comfortable. She could share with the group what she sees daily and how she reacts to this stimuli.

The advanced psychiatric nurse practitioner can slowly facilitate this conversation into feelings, focusing on how the nurse involved with the termination of the pregnancy felt then and how she is feeling now. A context for telling a story and creating meaning will be created (Miller, 1992:58-60). The advanced psychiatric nurse practitioner also needs to be reflective on the process of the group and therefore needs to keep brief data notes on a weekly basis for the purpose of maintaining continuity of the support group discussion (Guillory \& Riggin, 1991:173). The nurses involved with the women who chose to terminate a pregnancy could also be asked to keep a reflective diary, entering reflections of their experiences of working with these woman and reflecting on their interactions with meaningful, significant others (colleagues and family). This could be brought to the support group as means of discussion (Burns \& Grove, 1993:387).

Hamilton and Kieter (in Burkes, 1998:111) also suggest that the following questions could be useful in the opening phase of a support group:

What is the purpose of this new support group? How will the meetings be structured/unstructured? Will speakers of presentations be part of this support group?

How frequently will this group get together and what time of the day?

How long will the meetings last?

Where will the meetings be held?

How do we plan to announce meetings - by mail, word of mouth or phone?

Does anyone in the organisation need to be notified about the existence of the group?

Any refreshments?

The name of this group?

Nurses who have made the choice to work with women who chose to terminate a pregnancy have to learn to care more for each other and give more support to one another.

\section{Working phase}

\section{Out of the prison of confusion (value clarification)}

Those who come in contact with the emotional needs of the patient need some support and reflection for themselves. The goal in this phase might be to explore the nurses' perception of their values and how these might relate to perceptions regarding patients. The central concern will be to explore why the nurses involved with termination of a pregnancy experi- 
ence the predicament of an unwanted pregnancy in such judgmental terms. Could this be an argument best understood by unpacking and exploring their identity as nurses, mothers and wives? According to Walker (1994:43-67) in this discourse abortion symbolises a denial of a woman's true calling.

One aspect that needs to be addressed in this group is the issue of role-clarification. On the one hand nurses are compelled to adhere to legislation and on the other hand nurses are socialised as caregivers.

As such they are expected to empathize with and understand the very difficult and often traumatic experiences women have when faced with the predicament of an unwanted pregnancy (Walker, 1994:70-71)

Most of the women in this study were African nurses and as Walker (1994:58) states: "Role conflict might be heightened by the high status held by African nurses in their community. African nurses are members of the Elite in their communities, as evidenced by their friendships, lifestyles and membership of professional and voluntary organisations." As discussed previously this lead to the nurses becoming secretive about their work, related to fear for stigmatization and victimization. Christianity also proves to be a significant source of inner conflict regarding abortion. These questions of religion and morality need to be dealt with in this group. When nurses are confronted with the question of abortion they overwhelmingly tend to retreat into cold indifference. They withdraw from their patients and do not empathize with or take action to help their patients in any way (Walker, 1994:58-59). This could be dealt with by enhancing ethical-moral reasoning and behaviour. According to Brammer and Shoström (1989:340-341) the nurse should be helped to develop more complex processes for making value decisions based on reflection of their ultimate values. The nurse involved with termination of pregnancy needs to focus more inwardly, and learn to trust what he or she uncovers from his or her core being. The task of the advanced psychiatric nurse practitioner will be to help nurses involved with the termination of pregnancy to examine their implicit beliefs, to know how they are projecting their core values and to see how they perceive external values. These core values are learned during a growing-up process from values held by parents and others close to the person. According to Brammer, Shoström and Abrego (1989:343) the structure that constitutes reasoning about value issues involves the following set of interrelated mental activities, and could be utilized as a framework in this support: group to clarify beliefs and values:

1. Conceptualization/awareness and qualification of values by utilizing value clarification worksheets (Shelly \& Miller, 1991:29-38).

2. Interpretation of values with possible referral to biblio therapy or pastoral counseling. Determination of possible meanings.

3. Consideration of probable consequences of specific acts on self and others.

4. Judgment about what to do.

5. Supervision of judgment while remaining open to new information.

Brammer, Shoström and Abrego (1989:343) also suggest that the advanced psychiatric nurse practitioner can enter into dialogue with the nurses involved with termination of pregnancy to help them engage in reflective activity, entailing systematic questioning and listening, to discover contradictions, distractions, discrepancies and hidden meanings in beliefs and values underlying their decisions.

LeBaron and Carstarphen (1997:341-358) agree that these value issues/conflicts could be dealt with in small groups where personal interaction is possible. In these groups, members share stories of how they came to their belief about abortion. The small group activities are designed to break down stereotypes and allow each other to reveal shared concerns, hopes and values. Through this whole process trust and empathy must be fostered.

Act of reliving and remembering personal trauma / Addressing the monstrous consequences of psychological defense mechanisms

Psychological defense mechanisms act as a shield of protection against emotional pain. Many of these nurses intellectualized and rationalized their experiences regarding their involvement in termination of pregnancy. According to Richards, Cozzarelli, Cooper and Zubek (1998:735-752) the more women coped with their abortion-related emotions through avoidance strategies, the less well adjusted they were.

Coping with abortion-related emotions through seeking social support was associated with lowered levels of psychological distress. The aim of this group will then be to facilitate ventilation of feelings, and addressing defense mechanisms through illiminating the process and activating the here and now.

The aim is not just to focus on the explicit content (spoken words) but to ask the question: "What do these explicit words, the style of the participants, the nature of the discussion, tell about the interpersonal relationships of the group members, and of the group member him-/herself". By reflecting on this, the group members will also have the opportunity to explore their own personal worlds and reflect back on that (Yalom, 1998:45). Thus the advanced psychiatric nurse practitioner focus on the meta-communicational aspects of the message and wonder why, from the relationship aspect, the nurses make a statement at a certain time in a certain manner to a certain person. As the group progress and build trust, the advanced psychiatric nurse practitioner can also steer the group into the here and now, away from the discussion of outside material and focus their energy on their relationships with each other coming from the same clinic, in order for them to be able to provide feedback to each other's behaviour, and develop more reflexivity about their own interpersonal skills. A balance between structure and space for personal reflection needs to be provided to break down the defenses against anxiety (Franks, Watts \& Fabricius, 1994:1168).

\section{The community and the wall of silence}

Silence in this context lies in the unpacking and exploration of these nurses' identity as women, mothers and nurses. The constructed meanings they have about the above, need to be explored. For most of these nurses ideas about womanhood and motherhood are intricately interwoven and culturally determined (Walker, 1994:47).

Another voice introducing silence, is the power of men commanding obedience from African women in this context. The nurses need to voice these silences and generate new meanings to this story. A way of doing this would be to consult the consultants - the advance psychiatric nurse practitioner can consult the community leaders in generating a new story for these nurses or consult the nurses themselves.

According to Epston and White (1989-1991:17) when people are established as consultants to themselves, to others and to the therapist, they experience themselves more of an authority on their own lives, their problems and the solutions to these problems. Special attention could be given to an exploration of how they arrived at this knowledge, and how this knowledge affects their lives. 


\section{Termination phase}

In the process of reconstruction the hope would be in the end to provide a context where the nurse involved with termination of pregnancy, felt love form him-/her-self, allow others to care and to love her/him and to be more reflective and to search and trust his/her own values. Termination is but a stage in the nurse's career of growth, and is not tantamount to stagnation (Yalom, 1975:369). Nurses involved with termination of pregnancy will continue to change and derive new meanings from their experiences. According to Yalom (1975:369) not only growth, but also setbacks occur following termination and some of the nurses might encounter stress, anxiety and depression following departure from the group. A period of mourning is an inevitable part of this phase. The group may need some sessions to work on their loss and to deal with many of these termination issues. The advanced psychiatric nurse practitioner needs to call the nurses' attention to the impending termination. The group might be reminded that this is their group and they can decide how they want to end it. The final meeting can be embraced by personal testimonials, reminding one another of the way they were then, and how they are now, reflecting on the entries in their diaries. These new and different meanings can also be documented in discourse and within the diaries. White and Epston (19891991:16) found the following approaches helpful in reviewing their exploration of practices of re-incorporation, and reconstruction can involve the identification of change and could include:

- $\quad$ Celebrations and prize givings and awards, attended by significant others.

- Purposeful "new releases" where pertinent information as to the nurses' arrival at a new story/meaning is made available through one another to one another (reflexivity).

- Personal declarations and letters of reference.

- Consulting the community in a formal sense in relation to the solutions/ knowledge that have enabled them to free their lives.

The advanced psychiatric nurse practitioner needs to facilitate the process throughout, by reflecting on her/his own feelings about separation and ideas around reconstruction (Yalom, 1975:374).

\section{Conclusion}

The process of deconstruction assist in establishing a sense of empowerment for nurses involved with termination of pregnancy - being able to play an active role in the shaping of their own lives and their involvement with termination of pregnancy. This sense of empowerment is established through a process of co-construction through the development of some awareness of the degree to which extent their involvement with termination of pregnancy shape their existence. This provokes in the advanced psychiatric nurse practitioner a curiosity with regard to alternative versions of who these nurses might be. This is a curiosity of how things might be otherwise and different, in reconstructing new and different meanings. 


\section{References}

Act no 92 of 1996. Act on the freedom of choice in terminating pregnancy.

Andersen, T. 1987. The reflecting team. Family Process, 26, 1987:415-428.

Badenhorst, E. 1999. Aborsie eis al 60 000. Rapport, 7 February: 13.

Barometer, 1997: Vol. 1(2). Reproductive Rights Alliance.

Beeld, 1997:5

Barker, E. 1987. Support groups: Holistic. Nursing Journal of Neuroscience Nursing, 19(3): 121-122.

Brammer, L.M., Shoström, E.L., \& Abrego, P.J. 1989. Therapeutic psychology. New Jersey: Prentice Hall.

Burkes, R.G. 1998. The importance of support groups in nursing. NSNA/IMPRINT 1998:111.

Burns, N. \& Grove, S.K. 1993. The practice of nursing research. Philadelphia: W.B. Saunders.

Copi, I.M. 1986. Informal logic. New York: Macmillan.

Creswell, J.W. 1994. Research design, qualitative and quantitative approaches. California: Sage.

Democratic Nurses Association of South Africa. 1998. Ethical measures in research. Pretoria: DENOSA.

Epston, D. 1994. Extending the conversation. Family Networker, :31-39. Nov/Dec.

Epston, D. \& White, M. 1989-1991. Experience contradiction. Narrative and imagination - selected papers. South Australia: Dulwich Centre Publications.

Franks, V., Watts, M. \& Frabricius, J. 1994. Interpersonal learning in groups. Journal of Advanced Nursing,(20): 11621169.

Gmeiner, A.C., Van Wyk, S., Poggenpoel, M. \& Myburgh, C.P.H. 1999. Support for nurses directly involved with women who chose to terminate a pregnancy. Unpublished article.

Guillory, B.A. \& Riggin, O.Z. 1991. Developing a nursing staft support group model. Clinical Nurse Specialist, 5(3):170173.

Krefting, L .1990. Rigor in qualitative research: The assessment of trust. The American Journal of Occupational Therapy, 45(3): 214-222.

Kvale, S. 1996. Interviews: An introduction to qualitative research interviewing. London: Sage.

LeBaron, M. \& Carstarphen, N. 1997. Negotiation intractable conflict: The common grand dialogue process and abortion.

Lincoln, Y.S. \& Guba, E.G. 1985. Naturalistic Inquiry. London: Sage.

Marshall, C. \& Rossman, G.B. 1995. Designing qualitative research. Newbury: Sage.

Mouton, J. 1996. Understanding social research. Pretoria: Van Schaik.

Mouton, J. \& Marais, H.C. 1992. Basiese begrippe: Metodologie van Geesteswetenskappe. Pretoria: Raad vir Geesteswetenskaplike Navorsing.

McDonald, C.A. 1994 . Recruitment, retention and recognition of frontline workers in long-term care. Frontline Workers in Long-Term Care, Fall 194:38-41.

Miller, D.M. 1992. Care for the caregiver. $R N, 55$ Sept. 1992:58-60.

Omery, A. 1983. Phenomenology: A method for nursing research. Advances in Nursing Science, 5(2): 49-63.

Poggenpoel, M., Myburgh, C. \& Gmeiner, A. 1998. The Impact of legalization of abortion in South African health services with specific reference to the nursing profession.

Poggenpoel, M .1993. Phenomenological research: summary. Auckland Park: Rand Afrikaans University (Unpublished article).

Richards, B.M., Cooper, M.L., Cozzarelli, C. \& Zubek, J. 1998. Personal resilience, cognitive appraisal and coping: An integrative model of adjustment to abortion. Journal of personality and social psychology, 74(3): 735-752

Shelley, J.A. \& Miller, A.B. 1991. Values in conflict. New York: Intervarsity Press.

Walker, L. 1994. Discourses of patriarchy and power among African nurses in South Africa. African Studies, 55(2): 42-67.

Weiner, M., Caldwell, T. \& Tyson, J. 1983. Stresses and coping in ICU nursing: Why support groups fail. General Hospital Psychiatry, 5:179-183.

Wilson, H.S. \& Kneisl, C.R. 1996. Psychiatric nursing. California: Addison Wesley.

Wilson, H.S. 1989. Research in nursing. Second edition. Redwood City, California: Addison Wesley.

Yalom, I.D. 1975. The theory and practice of group psychotherapy. Second edition. New York: Basic Books.

Yalom, I.D. 1985. The theory and practice of group psychotherapy. New York: Hooper-Collins Publishers.

Yalom, I.D. 1998. The Yalom reader - selections from the work of a master therapist and storyteller. New York: Basic Books.

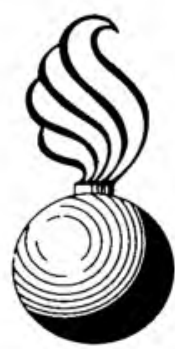

